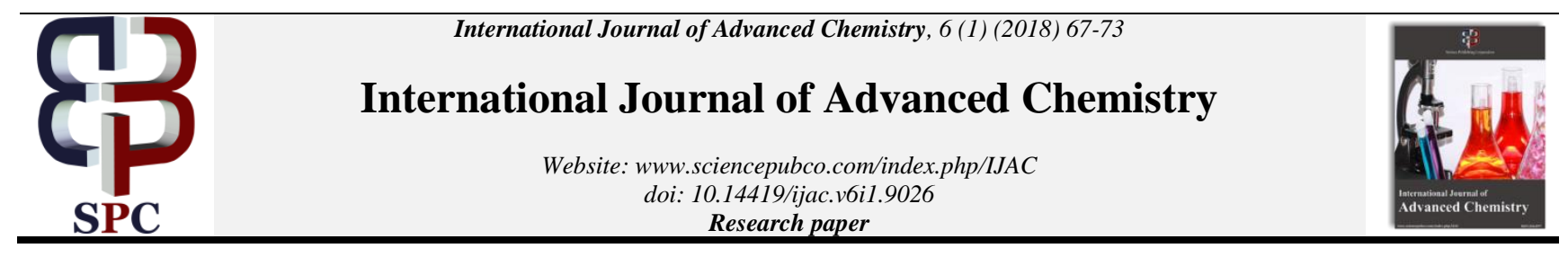

\title{
Theoretical calculation of influence of halogen atoms (F, Cl, Br, I) on arylazopyridine (Azpy) ruthenium complexes behaving as photo sensitizers by DFT method
}

\author{
N'guessanKouakou Nobel, OuattaraWawohinlin Patrice, KafoumbaBamba *, NahosséZiao \\ Laboratoire de Thermodynamique et de PHysico-Chimie du Milieu, UFR-SFA, UniversitéNanguiAbrogoua, \\ 02 B.P. 801 Abidjan 02, Côte d'Ivoire \\ *Corresponding author E-mail:bambakaf_sfa@una.edu.ci
}

\begin{abstract}
Photosensivity prediction of several azopyridine ruthenium complexes by DFT and TDDFT methods was performed. $\gamma$-RuX 2 (Azpy) 2 and $\delta$ - $\mathrm{RuX}_{2}(\text { Azpy })_{2}$ where $\mathrm{X}$ stands for $\mathrm{F}, \mathrm{Cl}, \mathrm{Br}$ and I were studied todetermine their activities when halide atoms shift. So, frontier orbital, NBO, NLMO and MLCT transitions as well as an excited lifetime of those complexes was determined. The main difference between them stems from both the electronegativity of the halide atoms and the structure of each complex. Hence, the rank of halide's electronegativity that is as follows $\chi_{\mathrm{p}}(\mathrm{F})>\chi_{\mathrm{p}}(\mathrm{Cl})>\chi_{\mathrm{p}}(\mathrm{Br})>\chi_{\mathrm{p}}(\mathrm{I})$ has been discovered to influence all the reactivity of the complexes regardless their structure. Herein, the comparison with the gap energy shows that the most reactive complexes are those with fluorine atom. Especially, $\delta-\mathrm{RuF}_{2}($ Azpy) 2 was admitted to be the most active isomer. Moreover, NBO calculation discloses that the complex becomes less ionic when the electronegativity decreases from F to I atoms. Furthermore, the calculation of NLMO orbitals shows that the bonding Ru-X are very strong. However, this strength decreases also from $\mathrm{F}$ to $\mathrm{I}$ and the nature of the bonding move from ionic to metallic. Moreover, the bonding from $\mathrm{N}_{\mathrm{py}}$ and $\mathrm{N}_{2}$ with $\mathrm{Ru}$ are known to be the same confirming the bidentate state of Azpy ligand. Regarding the electronic prediction, the eight complexes are surely assumed to display MLCT transitions that originate the photosensitivity. However, the complex that requires the least energy remains $\delta-\mathrm{RuF}_{2}(\mathrm{Azpy})_{2}$. This result was also determined by analyzing the excited lifetime that is the ability for a complex to longer linger in the cationic state. At last, we found out that with iodine atoms, the azopyridine ruthenium complex cannot behave as photosensitize dye insofar as I atom hides the main orbitals from $\mathrm{Ru}$ regardless the symmetry.
\end{abstract}

Keywords: Azopyridine; Halide Atoms; NBO; NLMO; Ru(II) Complexes.

\section{Introduction}

Since 1980, the ligand 2-Arylazopyridine complexing ruthenium atom is of great interest. It is used either as photo sensitizer to harvest electricity or as drug against cancer disease (Reedijk \& Bouwman 1999, Reedijk 2003). It is also used as a catalyst to oxidize high-value molecules (Jorna et al. 1996). The advantage of exploiting this ligand is that it is bidentate (Affi et al. 2015). It is a $\pi$ Acceptor and it reduces the state of oxidation of the metal to $+\mathrm{II}$ rendering it more selective. Thus, it binds metal remarkably well. Especially, $\mathrm{RuCl}_{2}$ (Azpy) ${ }_{2}$ as has been the most exploited of all azopyridine complexes ever yielded up to day (Krause et al. 1980, Boa et al. 1988).

In this work, we intend to predict the optical asset and the reactivity of azopyridine ruthenium complex when the halide $\mathrm{Cl}$ is changed with $\mathrm{F}, \mathrm{Br}$ or I as they all belong to the same halogen group in the periodic table, and they are assumed to display similar activity regardless their size. However, halide atoms can be slightly different from one another in a molecule owing to the difference of their inner shield electrons. For instance, several of their properties like the Pauling's electronegativity and the atomic radius that is assumed to be responsible for their reactivities varies respectively as follows:

$$
\chi_{\mathrm{p}}(\mathrm{F})=3.98>\chi_{\mathrm{p}}(\mathrm{Cl})=3.16>\chi_{\mathrm{p}}(\mathrm{Br})=2.96>\chi_{\mathrm{p}}(\mathrm{I})=2.66
$$

And

$\mathrm{r}(\mathrm{F})=1.17 \AA<\mathrm{r}(\mathrm{Cl})=1.67 \AA<\mathrm{r}(\mathrm{Br})=1.82 \AA<\mathrm{r}(\mathrm{I})=2.06 \AA$

Hence, while the electronegativity lowers in the group, the size enhances. Moreover, certain molecules can be toxic while other can be harmless (Shriver \& Atkins 1999).

Besides, $\mathrm{RuBr}_{2}$ (Azpy) 2 and $\mathrm{RuI}_{2}$ (Azpy) 2 have experimentally been slightly studied. They are produced in the same way as $\mathrm{RuCl}_{2}$ (Azpy) 2 by mixing up $\mathrm{RuX}_{3}, 3 \mathrm{H}_{2} \mathrm{O}(\mathrm{X}=\mathrm{Cl}, \mathrm{Br}$ and $\mathrm{I})$ and Azpy ligand (Gowami et al. 1981, Krause \& Krause 1982). Although it is reported that five isomers are expected for each complex owing to the asymmetry of the Azpy ligand, only two of them are hitherto produced by the following aforementioned process (Bamba et al. 2004, Velders et al. 2004) as displayed in Fig. 1. 


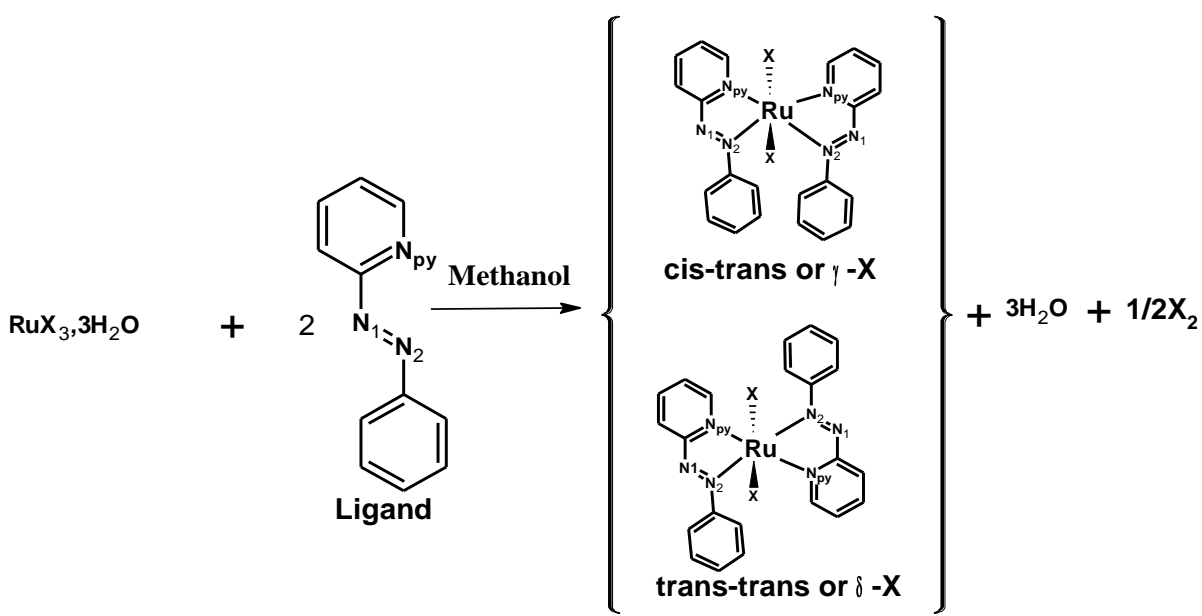

Fig.1:Synthesis of Azopyridine Ruthenium Complexes. in this Paper, X Stands for Halogen Atoms F, Cl, Br Or I. in Both Structures, Halogen Atoms are in Trans Position.

To best assure the explanation and the understanding of the subject, Fig. 2 displays the labeled ligand 2-phenylazopyridine (Azpy). It has been somewhat studied in our previous article (Affi et al. 2015, Bamba et al. 2016). Thus, we want to know of its mode of binding with the ruthenium when the halogen atoms are substituted.

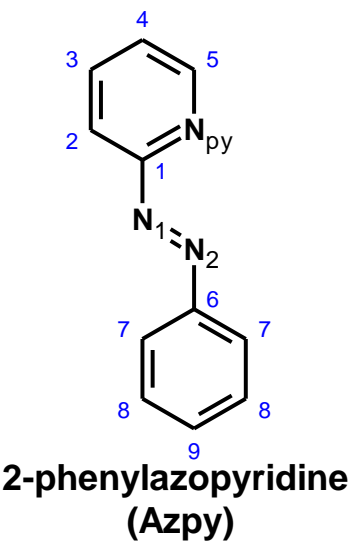

Fig.2:CommunAzopyridine Ligand Involved in the Formation of the Complexes $\operatorname{Rux}_{2}($ Azpy) $2,(\mathrm{X}=\mathrm{F}, \mathrm{Cl}, \mathrm{Br}$ or I). OnlyCarbon Atoms are numbered in Blue to Ease the Explanation of NLMO Theory. Thus, Those Numbers Are Different From That of Nitrogen Atoms in Azo Group Fragment.

\section{Method}

In this work, all calculations were undertaken with DFT method. In fact, the functional B3LYP was used with a separated basis set that comprises the pseudo-potential Lanl2dz exclusively for ruthenium and $6-31 \mathrm{G}$ (d) for the remaining atoms within the complex. This method is assumed to provide more accurate result consistent with experimental one. First, all molecules were optimized to find out the minimal energy that corresponds to the stationary point, then the frequency prediction was carried out to account for a lack of imaginary vibrational data. Regarding electronic prediction, it was carried out using the Time Dependent DFT (TDDFT) method with the same combined aforementioned basis set. Here, only absorption (vertical) energy is determined since it is admitted to be consistent with the experimental data (Adamo\&Jacquemin 2013). Also, the Natural Bond Orbital NBO and the Natural Localized Molecular Orbital NLMO were used respectively to predict the atomic charge and to perform the mode of binding of the ligand to the ruthenium ion (Weinhold \& Landis 2001), they were calculated thanks to the same separated basis set. In all the case, the whole calculations were performed using Gaussian 03 package (Frisch et al. 2003).

\section{Results and discussion}

\subsection{Predicted geometrical parameters of the complexes}

Table 1: Calculated Selected Bond Lengths $(\AA)$ and Angles Bond (Deg) of $\gamma, \delta$ $\operatorname{Rux}_{2}(\mathrm{Azpy})_{2}(\mathrm{X}=\mathrm{F}, \mathrm{Cl}, \mathrm{Br}$ and I $)$

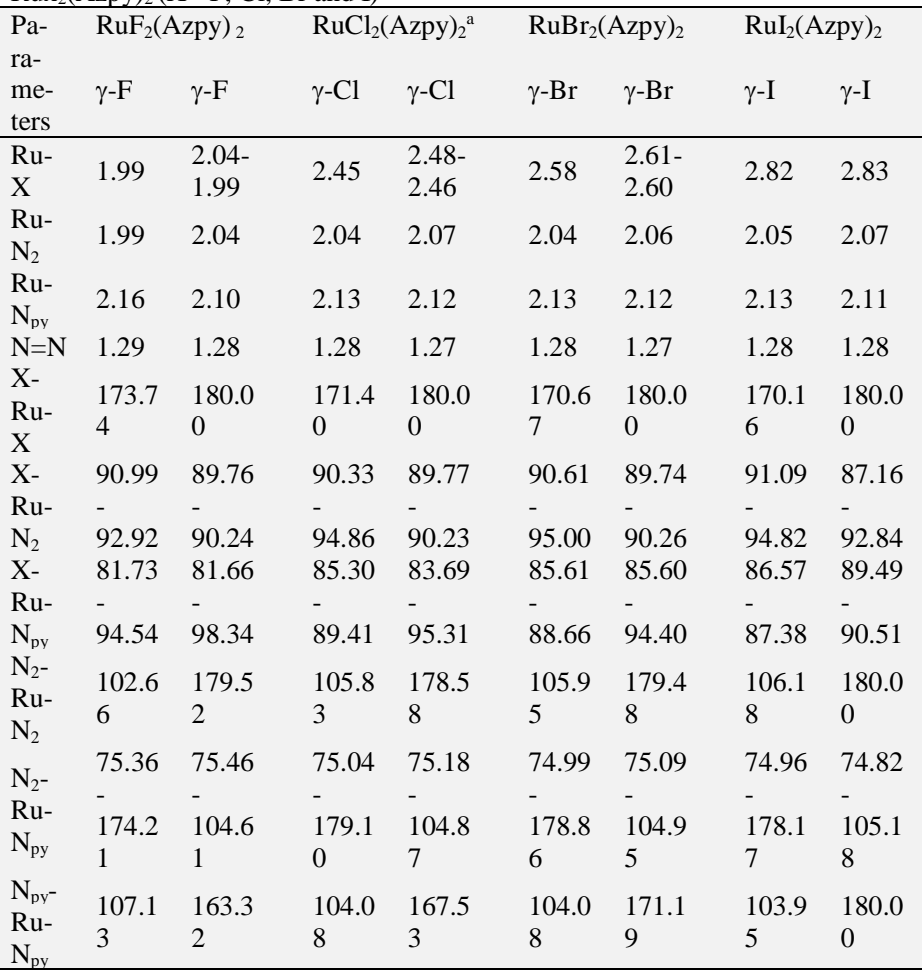

${ }^{\mathrm{a}}$ experiment data are taken from (Misra et al. 1997).

The main bonds and angles that characterize both metal and azopyridine ligand are displayed in Table 1 . Regarding $\gamma$-X isomers, we can see that $\gamma-\mathrm{RuF}_{2}$ (Azpy) 2 shows the shortest $\mathrm{Ru}-\mathrm{X}$ bond with $1.99 \AA$ and the longest bond is given by $\gamma-\mathrm{RuI}_{2}$ (Azpy) 2 . The order of that Ru$\mathrm{X}$ bond is presented as $\mathrm{Ru}-\mathrm{F}(1.99 \AA)<\mathrm{Ru}-\mathrm{Cl}(2.45 \AA)<\mathrm{Ru}-\mathrm{Br}(2.58 \AA)$ $<\mathrm{Ru}-\mathrm{I}(2.82 \AA)$. This result can be linked to the electronegativity of the halogen atoms in the periodic table in agreement with reference 3 . Thus the high electronegativity will strengthen the $\mathrm{Ru}-\mathrm{X}$ bond and thereby shortening its length. In consequence, a small shape of the molecule can be expected. Moreover, this same order was observed in the case of $\mathrm{Ru}-\mathrm{N}_{2}$ bond. However, regarding the Ru-N $\mathrm{N}_{\mathrm{py}}$ bond, except for $\gamma-\mathrm{F}$ whose bond length is $2.16 \AA$, we can see that almost the remaining complexes display an invariable bonds with $2.13 \AA$. Besides, $\gamma$-X isomers present only one data that characterizes each $\mathrm{Ru}-\mathrm{X}$ bond length. 
Which confirms a symmetry that allows each pair of atom to be in the same environment as we indicated in a previous paper (Nobel et al. 2017).Thus, those isomers are assumed to be $C_{2}$ symmetrical. For the angle bonds, we can see that $\mathrm{X}-\mathrm{Ru}-\mathrm{X}$ which value was set to $180^{\circ}$ before calculation for each isomer was reduced according to the following rank: I-Ru-I $\left(170.16^{\circ}\right)<\mathrm{Br}-\mathrm{Ru}-\mathrm{Br}\left(170.67^{\circ}\right)<\mathrm{Cl}-\mathrm{Ru}-\mathrm{Cl}\left(171.4^{\circ}\right)<\mathrm{F}-\mathrm{Ru}-$ $\mathrm{F}\left(173.74^{\circ}\right)$. Thus, the iodine atom reduces the angle more when the fluorine atom modifies it less. We can conclude furthermore that the shape of the halogen atom reduces the $\mathrm{X}-\mathrm{Ru}-\mathrm{X}$ angle bond within the molecule in the order $(\mathrm{F}<\mathrm{Cl}<\mathrm{Br}<\mathrm{I})$. Concerning the $\mathrm{N}_{\mathrm{py}}-\mathrm{Ru}-\mathrm{N}_{\mathrm{py}}$ angle bonds, they keep the same rank as $\mathrm{X}-\mathrm{Ru}-\mathrm{X}$ aforementioned. However, the $\mathrm{N}_{2}-\mathrm{Ru}-\mathrm{N}_{2}$ bonds show the contrary rank. Anyway, we can admit that the size of cis-RuX 2 (Azpy) 2 increases from $\mathrm{F}$ to $\mathrm{I}$ atom in relation to their electronegativity and their atomic radius.

Regarding $\delta$-X isomers where both azopyridine ligands are in trans position, the $\mathrm{Ru}-\mathrm{F}, \mathrm{Ru}-\mathrm{Cl}$ and $\mathrm{Ru}-\mathrm{Br}$ bonds are represented by two values thereby indicating that both halogen atoms are in different environment. Nevertheless, they are assumed to display a $\mathrm{C}_{2}$ symmetry (Bamba et al. 2016). Yet, Ru-I displays one bond length. It shows up a center of symmetry. Therefore, it is a $\mathrm{C}_{\mathrm{i}}$ symmetrical molecule. Besides, this structure was confirmed by its angle bonds regarding I-Ru-I, $\mathrm{N}_{\mathrm{py}}-\mathrm{Ru}-\mathrm{N}_{\mathrm{py}}$ and $\mathrm{N}_{2}-\mathrm{Ru}-\mathrm{N}_{2}$ that values still remain $180^{\circ}$ indicating that atoms in opposite positions through the $\mathrm{Ru}$ atom within the complex are identical by pair. Concerning Ru-X bonds, they increase from $\mathrm{F}$ to $\mathrm{I}$ however Ru-N bonds remain slightly the same. Herein, we can assume that electronegativity has no effect on $\mathrm{Ru}-\mathrm{N}$ bonds. Anyhow, we can assume again that the shape of the complex increases from fluorine to iodine atoms regardless the structure of the isomer.

\subsection{Electronic structures}

\subsubsection{Frontier molecular energy}

Table 2:Energies (Kcal/Mol) of Frontier Orbitals with Gap Energy $\Delta \mathrm{E}$ Calculated for Both $\gamma$ - and $\delta$-Rux (Azpy $_{2}$ Isomers

\begin{tabular}{lllllllll}
\hline & \multicolumn{2}{c}{$\mathrm{RuF}_{2}(\mathrm{Azpy})_{2}$} & \multicolumn{2}{c}{$\mathrm{RuCl}_{2}(\mathrm{Azpy})_{2}$} & \multicolumn{2}{c}{$\mathrm{RuBr}_{2}(\mathrm{Azpy})_{2}$} & \multicolumn{2}{l}{$\mathrm{RuI}_{2}(\mathrm{Azpy})_{2}$} \\
& $\gamma-\mathrm{F}$ & $\gamma-\mathrm{F}$ & $\gamma-\mathrm{Cl}$ & $\gamma-\mathrm{Cl}$ & $\gamma-\mathrm{Br}$ & $\gamma-\mathrm{Br}$ & $\gamma$-I & $\gamma-\mathrm{I}$ \\
\hline HOMO & - & - & - & - & - & - & - & - \\
$(\mathrm{H})$ & 111. & 105. & 119. & 116. & 117. & 114. & 119. & 117. \\
& 7 & 65 & 41 & 03 & 92 & 66 & 68 & 25 \\
LUMO & - & - & - & - & - & - & - & - \\
$(\mathrm{L})$ & 66.5 & 67.4 & 70.2 & 71.7 & 69.5 & 71.3 & 71.0 & 72.9 \\
& 2 & 1 & 2 & 2 & 0 & 4 & 0 & 9 \\
NHOMO & - & - & - & - & - & - & - & - \\
$(\mathrm{H}-1)$ & 119. & 115. & 126. & 123. & 123. & 121. & 123. & 122. \\
& 33 & 07 & 24 & 73 & 33 & 07 & 51 & 31 \\
NLUMO & - & - & - & - & - & - & - & - \\
$(\mathrm{L}+1)$ & 51.5 & 51.4 & 64.0 & 63.4 & 58.3 & 55.7 & 70.3 & 69.0 \\
& 5 & 3 & 0 & 0 & 5 & 4 & 0 & 0 \\
$\Delta \mathrm{E}^{\mathrm{a}}$ & 45.1 & 38.2 & 49.1 & 44.3 & 48.4 & 43.3 & 48.6 & 44.2 \\
& 8 & 4 & 9 & 1 & 2 & 2 & 8 & 6 \\
$\eta$ & 22.5 & 19.1 & 24.5 & 22.1 & 24.2 & 21.6 & 24.3 & 22.1 \\
& 9 & 2 & 95 & 55 & 1 & 6 & 4 & 3 \\
$\mu$ & - & - & - & - & - & - & - & - \\
& 89.1 & 86.5 & 94.8 & 93.8 & 93.7 & 93.0 & 95.3 & 95.1 \\
& 1 & 3 & 15 & 75 & 1 & 0 & 4 & 2 \\
\hline
\end{tabular}

Table 2 displays the frontier molecular orbitals and their relatives who comprise the highest occupied molecular orbital (HOMO), the lowest unoccupied molecular orbital (LUMO), the energy gap $(\Delta \mathrm{E})$, the chemical hardness $(\eta)$ and the chemical potential $(\mu)$. As highlighted in our previous article (Bamba et al. 2016), they are assumed to define the reactivity of the molecule. The objective of our work therein was to see the state of the reactivity of the azopyridine ruthenium complex when only the modified parameter was the azopyridine ligand. Herewith, it resulted that the most reactive complex was $\delta-\mathrm{RuCl}_{2}$ (Azpy) ${ }_{2}$ due to its shallow energy gap. Now, we need to modify the halogen parameter thereby keeping Azpy as azopyridine ligand and Ru as the metal center atomic. Actually, frontier orbitals provide two types of information: The first regards the internship reaction that stresses the reactivity of the molecule as formerly explained (Bamba et al. 2016). Therefore, the most active molecule is of course the one whose gap energy and hardness are very low. So, based on that analysis, we can assume that the most active molecule is still $\delta$-X. More specifically, $\delta-\mathrm{RuF}_{2}$ (Azpy) ${ }_{2}$ is assumed to be the most active and the softest complex. The second information deals with reaction between two molecules. For instance, we consider the reaction between the azopyridine ruthenium complexes and DNA molecules insofar as the complex has been studied as a cytotoxic molecules. In this case, the complex is assumed to receive an electron from DNA molecule. In consequence, it must have a its low LUMO orbital higher than the HOMO orbital of the DNA. From this analysis, we can see that comparing both types of isomers, $\delta$-X displays the lowest LUMO energy. Otherwise, $\delta$-Xis the most active molecule to react with DNA.

\subsubsection{NBO prediction}

NBO analysis characterizes the electronic structure of each atom in the molecule. Hence, Table 3 displays the natural population of the ruthenium both in complex or as atomic. We can see here that the core electrons do not undergo any modification and are composed of 36 electrons. Regarding the valence orbital, the number of electron increases from fluorine atom to iodine atom. However, for Rydberg electrons, there are high for fluorine atom with $0.09 \mathrm{e}^{-}$and constant for other's atoms with $0.06 \mathrm{e}^{-}$. Consequently, the total electron population also increases from fluorine to iodine atoms. Therefore, the natural charge of the ruthenium slightly decreases. Through Table 3, we can see that the natural charge of ruthenium may depend only on the electronegativity of halogen atoms. To check this statement, Table 4 displays the natural charge of the main atoms involved in the bonding to the ruthenium atom. Here, we can see that the charge of the three nitrogen atoms both through the ligand isolated, and in the complexes is invariable. Therefore, it can be assumed that the ligand is not responsible for the natural charge of ruthenium. However, the charge of the halogen atoms alters according to their electronegativity regardless the isomer. Besides, we can see that in each $c i s(\gamma-\mathrm{X})$ isomer, the charge of both halogen atoms is the same confirming the $\mathrm{C}_{2}$ symmetry of the complexes. Whereas the trans isomer, it displays different charge for both halogen atoms, although they are also $\mathrm{C}_{2}$ symmetrical. Contrary for $\delta \mathrm{RuI}_{2}(\mathrm{Az}-$ py)2, the complex is assumed to be $\mathrm{C}_{\mathrm{i}}$ symmetrical. Therefore, it presents both iodine atoms with the same charge -0.45 .

Table 3:Allotment of Electrons of Ruthenium as Ion when It Is Involved in the Complex or as Atom. This Distribution Is Made Between Core, Valence and Rydberg Orbitals

\begin{tabular}{|c|c|c|c|c|c|}
\hline & CORE & VALENCE & RYDBERG & TOTAL & Charge $\mathrm{Ru}$ \\
\hline$\gamma \operatorname{RuF}_{2}(\mathrm{Azpy})_{2}$ & 35.99 & 7.05 & 0.09 & 43.13 & 0.87 \\
\hline$\delta \mathrm{RuF}_{2}(\text { Azpy })_{2}$ & 35.99 & 7.08 & 0.09 & 43.16 & 0.84 \\
\hline$\gamma \mathrm{RuCl}_{2}(\text { Azpy })_{2}$ & 35.99 & 7.43 & 0.06 & 43.48 & 0.52 \\
\hline$\delta \mathrm{RuCl}_{2}(\mathrm{Azpy})_{2}$ & 35.99 & 7.45 & 0.06 & 43.50 & 0.50 \\
\hline$\gamma \operatorname{RuBr}_{2}(\text { Azpy })_{2}$ & 35.99 & 7.51 & 0.06 & 43.56 & 0.44 \\
\hline$\delta \operatorname{RuBr}_{2}(\text { Azpy })_{2}$ & 35.99 & 7.52 & 0.06 & 43.57 & 0.43 \\
\hline$\gamma \mathrm{RuI}_{2}(\text { Azpy })_{2}$ & 35.99 & 7.62 & 0.06 & 43.67 & 0.33 \\
\hline$\delta \mathrm{RuI}_{2}(\mathrm{Azpy})_{2}$ & 35.99 & 7.62 & 0.06 & 43.67 & 0.33 \\
\hline $\mathrm{Ru}$ atom & 36.00 & 8.00 & 0.00 & 44.00 & 0.00 \\
\hline
\end{tabular}

Table 4: Charge of the Main Atoms Involved in Reaction in the Azopyridine Ruthenium Complex

\begin{tabular}{|c|c|c|c|c|c|c|c|}
\hline & \multirow{2}{*}{ Isomer } & \multicolumn{6}{|c|}{ Atoms } \\
\hline & & $\mathrm{Ru}$ & $\mathrm{N}_{\mathrm{py}}$ & $\mathrm{N}_{1}$ & $\mathrm{~N}_{2}$ & $\mathrm{X}$ & \\
\hline \multirow{2}{*}{$\mathrm{RuF}_{2}(\text { Azpy })_{2}$} & Cis & 0.87 & -0.46 & -0.24 & -0.11 & -0.59 & -0.59 \\
\hline & Trans & 0.84 & -0.43 & -0.21 & -0.13 & -0.60 & -0.62 \\
\hline \multirow{2}{*}{$\mathrm{RuCl}_{2}(\mathrm{Azpy})_{2}$} & Cis & 0.52 & -0.42 & -0.22 & -0.10 & -0.54 & -0.54 \\
\hline & Trans & 0.50 & -0.41 & -0.19 & -0.11 & -0.55 & -0.57 \\
\hline \multirow{2}{*}{$\mathrm{RuBr}_{2}(\mathrm{Azpy})_{2}$} & $\mathrm{Cis}$ & 0.44 & -0.43 & -0.21 & -0.11 & -0.49 & -0.49 \\
\hline & Trans & 0.43 & -0.41 & -0.19 & -0.12 & -0.50 & -0.51 \\
\hline \multirow{2}{*}{$\mathrm{RuI}_{2}(\text { Azpy })_{2}$} & Cis & 0.33 & -0.44 & -0.20 & -0.12 & -0.44 & -0.44 \\
\hline & Trans & 0.33 & -0.42 & -0.18 & -0.13 & -0.45 & -0.45 \\
\hline Ligand Azpy & & & -0.44 & -0.23 & -0.15 & & \\
\hline
\end{tabular}




\subsubsection{NLMO calculations}

The natural localized molecular orbital (NLMO) tends to explain how bonding is performed between two atoms by displaying the molecular orbital (Reed et al. 1988). Table 5 shows the bondings that are set up for both isomers $\delta$-X and $\gamma$-X while $\mathrm{X}$ stands for $\mathrm{F}, \mathrm{Cl}, \mathrm{Br}$ and $\mathrm{I}$. The available atoms that are involved in the bondings are $\mathrm{Ru}, \mathrm{X}, \mathrm{N}_{\mathrm{py}}, \mathrm{N}_{1}$ and $\mathrm{N}_{2}$. We can see that two types of bonding are possible: the strong covalent bonding that is directly formed between two atoms and the weak bonding represented by a lone pair orbital whose molecular orbital highlights all atoms involved in the bonding. This last bonding is admitted to be a vanderwaals one. As we can notice, only halogen atoms actually perform strong covalent bonding with the ruthenium. The total number of electrons (indicated by NBO calculation) that each halogen atom shares with the ruthenium atom is almost the same confirming thereby the $\mathrm{C}_{2}$ symmetry of both halide atoms. Moreover, we can assume that this high value regarding halogen atoms strengthens the theory arguing that the complex doesn't undergo any hydrolysis or substitution of halide atoms when binding to the DNA. So, the intercalation that is the most admitted theory for DNA to bind to the cytotoxic ruthenium complex must certainly be through the bonding with the ligand azpy (Chen et al. 2005). Moreover, as the $C_{2}$ symmetry means equality between opposite atoms through a $\mathrm{C}_{2}$ axis by pairs, we can notice on table 3 a sort of compensation between the contribution of both atoms in performing each lone pair orbital. For instance, in $\gamma$-X isomers, both $\mathrm{X}$ atoms should be identical by displaying the same molecular orbital. Otherwise, if one of the halide is involved in a strong covalent bonding for example $\mathrm{Ru}-\mathrm{X}_{1}$ and the other is concerned by $\mathrm{LP}\left(\mathrm{X}_{2}\right)$, then the first halide $\mathrm{X}_{1}$ atom will contribute in the bonding of the second to $\mathrm{Ru}$ insofar as the molecular orbital of $\mathrm{LP}\left(\mathrm{X}_{2}\right)$ shows up $\mathrm{X}_{1}$ as a contributor. Therefore, both halide will present almost the same amount of occupancy.

Table 5:Nlmos Indicating the Mode of Bonding Between The Ruthenium and Main Atomics Involved in the Formation of Rux ${ }_{2}(\mathrm{Azpy})_{2}$ with $\mathrm{X}=\mathrm{F}$, Cl, Br Or I. LP Means Lone Pair Orbital. It Is Admitted to Be the Main Donor of Electron to the Ruthenium Atom Thereby Forming A Weak Bonding. as the Complexes are Octahedral, the Bonding Is Performed Between Ru, X and N Atoms. Both Halide Atoms are Made Discernable by Numbers 1 and 2 to Better Understand the Theory

${ }^{\mathrm{a}} \mathrm{LP}$ means lone pair orbital;

\begin{tabular}{|c|c|c|c|c|}
\hline \multirow[t]{3}{*}{$\begin{array}{l}\text { NLM } \\
\mathrm{O}\end{array}$} & \multicolumn{4}{|l|}{$\mathrm{RuF}_{2}(\text { Azpy })_{2}$} \\
\hline & & $\gamma-\mathrm{X}$ & & $\delta-\mathrm{X}$ \\
\hline & $\begin{array}{l}\text { Occupan- } \\
\text { cies }(\%)\end{array}$ & Molecular orbital & $\begin{array}{l}\text { Occupan- } \\
\text { cies }(\%)\end{array}$ & Molecular orbital \\
\hline $\mathrm{LP}\left(\mathrm{F}_{1}\right)$ & 98.43 & $\sigma=82.52 \%\left(\mathrm{~F}_{1}\right)+15.91 \%(\mathrm{Ru})$ & 98.78 & $\sigma=79.62 \%\left(\mathrm{~F}_{1}\right)+19.17 \%(\mathrm{Ru})$ \\
\hline $\mathrm{LP}\left(\mathrm{F}_{2}\right)$ & 98.44 & $\sigma=82.51 \%\left(\mathrm{~F}_{2}\right)+15.93 \%(\mathrm{Ru})$ & 98.69 & $\sigma=84.60 \%\left(\mathrm{~F}_{2}\right)+11.37 \%(\mathrm{Ru})+2.72 \%\left(\mathrm{~F}_{1}\right)$ \\
\hline${ }^{L P}\left(N_{p y}\right.$ & 96.54 & $\sigma=85.53 \%\left(\mathrm{~N}_{\mathrm{py}}\right)+8.4 \%(\mathrm{Ru})+2.61 \%\left(\mathrm{~N}_{2}\right)$ & 94.00 & $\sigma=83.15 \%\left(\mathrm{~N}_{\mathrm{py}}\right)+10.84 \%(\mathrm{Ru})$ \\
\hline $\mathrm{LP}\left(\mathrm{N}_{1}\right)$ & 99.07 & $\begin{array}{l}\sigma= \\
96.26 \%\left(\mathrm{~N}_{1}\right)+1.01 \%\left(\mathrm{C}_{1}\right)+0.49 \%\left(\mathrm{~N}_{\mathrm{py}}\right)+0.41 \%\left(\mathrm{~N}_{2}\right)+0.9 \%(\mathrm{R} \\
\mathrm{u})\end{array}$ & 99.19 & $\begin{array}{l}\sigma= \\
96.71 \%\left(\mathrm{~N}_{1}\right)+0.92 \%\left(\mathrm{C}_{1}\right)+0.44 \%\left(\mathrm{~N}_{\mathrm{py}}\right)+0.35 \%\left(\mathrm{~N}_{2}\right)+0.77 \\
\%(\mathrm{Ru})\end{array}$ \\
\hline $\mathrm{LP}\left(\mathrm{N}_{2}\right)$ & 97.66 & $\sigma=77.88 \%\left(\mathrm{~N}_{2}\right)+19.78 \%(\mathrm{Ru})$ & 97.88 & $\sigma=81.21 \%\left(\mathrm{~N}_{2}\right)+16.67 \%(\mathrm{Ru})$ \\
\hline $\begin{array}{l}\mathrm{LP}(\mathrm{Ru} \\
)\end{array}$ & 84.63 & $\sigma=76.03 \%(\mathrm{Ru})+3.84 \%\left(\mathrm{~N}_{1}\right)+4.76 \%\left(\mathrm{~N}_{2}\right)$ & 82.80 & $\sigma=73.75 \%(\mathrm{Ru})+4.22 \%\left(\mathrm{~N}_{1}\right)+4.83 \%\left(\mathrm{~N}_{2}\right)$ \\
\hline \multicolumn{5}{|c|}{$\mathrm{RuCl}_{2}(\mathrm{Azpy})_{2}$} \\
\hline $\mathrm{Ru}-\mathrm{Cl}_{1}$ & 98.8 & $\sigma=72.90 \%\left(\mathrm{Cl}_{1}\right)+25.90 \%(\mathrm{Ru})$ & 98.66 & $\sigma=72.91 \%\left(\mathrm{Cl}_{1}\right)+25.75 \%(\mathrm{Ru})$ \\
\hline $\mathrm{LP}\left(\mathrm{N}_{\mathrm{py}}\right.$ & 96.97 & $\sigma=82.01 \%\left(\mathrm{~N}_{\mathrm{py}}\right)+11.72 \%(\mathrm{Ru})+3.24 \%\left(\mathrm{~N}_{2}\right)$ & 96.4 & $\sigma=83.10 \%\left(\mathrm{~N}_{\mathrm{py}}\right)+11.35 \%(\mathrm{Ru})+1.95 \%\left(\mathrm{~N}_{2}\right)$ \\
\hline $\mathrm{LP}\left(\mathrm{N}_{1}\right)$ & 99.13 & $\begin{array}{l}\sigma= \\
96.51 \%\left(\mathrm{~N}_{1}\right)+0.91 \%\left(\mathrm{C}_{1}\right)+0.46 \%\left(\mathrm{~N}_{\mathrm{py}}\right)+0.35 \%\left(\mathrm{~N}_{2}\right)+0.9 \%( \\
\mathrm{Ru})\end{array}$ & 99.22 & $\begin{array}{l}\sigma= \\
96.80 \%\left(\mathrm{~N}_{1}\right)+0.86 \%\left(\mathrm{C}_{1}\right)+0.40 \%\left(\mathrm{~N}_{\mathrm{py}}\right)+0.35 \%\left(\mathrm{~N}_{2}\right)+0.81 \\
\%(\mathrm{Ru})\end{array}$ \\
\hline $\mathrm{LP}\left(\mathrm{N}_{2}\right)$ & 97.77 & $\sigma=79.76 \%\left(\mathrm{~N}_{2}\right)+15.20 \%(\mathrm{Ru})+2.81 \%\left(\mathrm{~N}_{\mathrm{py}}\right)$ & 97.08 & $\sigma=81.07 \%\left(\mathrm{~N}_{2}\right)+16.01 \%(\mathrm{Ru})$ \\
\hline $\begin{array}{l}\mathrm{LP}(\mathrm{Ru} \\
{ }^{2}\end{array}$ & 87.00 & $\sigma=80.42 \%(\mathrm{Ru})+2.66 \%\left(\mathrm{~N}_{1}\right)+3.91 \%\left(\mathrm{~N}_{2}\right)$ & 87.07 & $\sigma=79.80 \%(\mathrm{Ru})+3.16 \%\left(\mathrm{~N}_{1}\right)+4.11 \%\left(\mathrm{~N}_{2}\right)$ \\
\hline \multicolumn{5}{|c|}{$\operatorname{RuBr}_{2}(\text { Azpy })_{2}$} \\
\hline $\mathrm{Ru}-\mathrm{Br}_{1}$ & 98.37 & $\sigma=69.42 \%\left(\mathrm{Br}_{1}\right)+28.95 \%(\mathrm{Ru})$ & 97.91 & $\sigma=68.27 \%\left(\mathrm{Br}_{1}\right)+29.64 \%(\mathrm{Ru})$ \\
\hline${ }^{\mathrm{LP}}\left(\mathrm{Br}_{2}\right.$ & 97.12 & $\sigma=75.58 \%\left(\mathrm{Br}_{2}\right)+15.36 \%(\mathrm{Ru})+6.18 \%\left(\mathrm{Br}_{1}\right)$ & 97.07 & $\left.\sigma=76.00 \% \mathrm{Br}_{2}\right)+14.72 \%(\mathrm{Ru})+6.35 \%\left(\mathrm{Br}_{1}\right)$ \\
\hline $\begin{array}{l}\mathrm{LP}\left(\mathrm{N}_{\mathrm{py}}\right. \\
)\end{array}$ & 96.95 & $\sigma=82.10 \%\left(\mathrm{~N}_{\mathrm{py}}\right)+11.66 \%(\mathrm{Ru})+3.19 \%\left(\mathrm{~N}_{2}\right)$ & 96.38 & $\sigma=81.34 \%\left(\mathrm{~N}_{\mathrm{py}}\right)+15.04 \%(\mathrm{Ru})$ \\
\hline $\mathrm{LP}\left(\mathrm{N}_{1}\right)$ & 99.13 & $\begin{array}{l}\sigma= \\
96.51 \%\left(\mathrm{~N}_{1}\right)+0.91 \%\left(\mathrm{C}_{1}\right)+0.45 \%\left(\mathrm{~N}_{\mathrm{py}}\right)+0.35 \%\left(\mathrm{~N}_{2}\right)+0.91 \\
\%(\mathrm{Ru})\end{array}$ & 99.22 & $\begin{array}{l}\sigma= \\
96.82 \%\left(\mathrm{~N}_{1}\right)+0.84 \%\left(\mathrm{C}_{1}\right)+0.40 \%\left(\mathrm{~N}_{\mathrm{py}}\right)+0.32 \%\left(\mathrm{~N}_{2}\right)+0.84 \\
\%(\mathrm{Ru})\end{array}$ \\
\hline LP(Ru & 87.15 & $\sigma=80.67 \%(\mathrm{Ru})+2.62 \%\left(\mathrm{~N}_{1}\right)+3.86 \%\left(\mathrm{~N}_{2}\right)$ & 87.11 & $\sigma=79.76 \%(\mathrm{Ru})+3.46 \%\left(\mathrm{~N}_{1}\right)+3.89 \%\left(\mathrm{~N}_{2}\right)$ \\
\hline \multicolumn{5}{|c|}{$\mathrm{RuI}_{2}(\text { Azpy })_{2}$} \\
\hline $\mathrm{Ru}-\mathrm{I}_{1}$ & 97.89 & $\sigma=65.05 \%\left(\mathrm{I}_{1}\right)+32.84 \%(\mathrm{Ru})$ & 97.70 & $\sigma=65.88 \%\left(\mathrm{I}_{1}\right)+31.84 \%(\mathrm{Ru})$ \\
\hline $\mathrm{LP}\left(\mathrm{I}_{2}\right)$ & 95.93 & $\sigma=72.64 \%\left(\mathrm{I}_{2}\right)+15.73 \%(\mathrm{Ru})+7.56 \%\left(\mathrm{I}_{1}\right)$ & 95.86 & $\sigma=73.11 \%\left(\mathrm{I}_{2}\right)+15.49 \%(\mathrm{Ru})+7.26 \%\left(\mathrm{I}_{1}\right)$ \\
\hline $\begin{array}{l}\mathrm{LP}\left(\mathrm{N}_{\mathrm{py}}\right. \\
)\end{array}$ & 96.96 & $\sigma=82.30 \%\left(\mathrm{~N}_{\mathrm{py}}\right)+11.58 \%(\mathrm{Ru})+3.08 \%\left(\mathrm{~N}_{2}\right)$ & 95.45 & $\sigma=83.04 \%\left(\mathrm{~N}_{\mathrm{py}}\right)+11.41 \%(\mathrm{Ru})+1 \%\left(\mathrm{~N}_{2}\right)$ \\
\hline $\mathrm{LP}\left(\mathrm{N}_{1}\right)$ & 99.15 & $\begin{array}{l}\sigma= \\
96.51 \%\left(\mathrm{~N}_{1}\right)+0.90 \%\left(\mathrm{C}_{1}\right)+0.44 \%\left(\mathrm{~N}_{\mathrm{py}}\right)+0.35 \%\left(\mathrm{~N}_{2}\right)+0.95 \\
\%(\mathrm{Ru})\end{array}$ & 99.23 & $\begin{array}{l}\sigma= \\
96.78 \%\left(\mathrm{~N}_{1}\right)+0.84 \%\left(\mathrm{C}_{1}\right)+0.40 \%\left(\mathrm{~N}_{\mathrm{py}}\right)+0.34 \%\left(\mathrm{~N}_{2}\right)+0.87 \\
\%(\mathrm{Ru})\end{array}$ \\
\hline $\mathrm{LP}\left(\mathrm{N}_{2}\right)$ & 97.72 & $\sigma=80.29 \%\left(\mathrm{~N}_{2}\right)+14.76 \%(\mathrm{Ru})+2.67 \%\left(\mathrm{~N}_{\mathrm{py}}\right)$ & 96.94 & $\sigma=81.13 \%\left(\mathrm{~N}_{2}\right)+15.81 \%(\mathrm{Ru})$ \\
\hline LP(Ru & 87.76 & $\sigma=81.90 \%(\mathrm{Ru})+2.36 \%\left(\mathrm{~N}_{1}\right)+3.50 \%\left(\mathrm{~N}_{2}\right)$ & 87.30 & $\sigma=80.06 \%(\mathrm{Ru})+3.43 \%\left(\mathrm{~N}_{1}\right)+3.81 \%\left(\mathrm{~N}_{2}\right)$ \\
\hline
\end{tabular}

${ }^{\mathrm{a}} \mathrm{LP}$ means lone pair orbital; 
Regarding the $\mathrm{RuF}_{2}$ (Azpy) 2, all the bondings in both types of isomers are carried out through the lone pair of halide or nitrogen atoms. Both halide atoms show almost the identical molecular orbital where the bonding is assumed to be performed mainly between the halide and the ruthenium atoms, i.e., $\mathrm{LP}\left(\mathrm{F}_{1}\right)=\mathrm{LP}$ $\left(\mathrm{F}_{2}\right)$. Besides in the trans $(\delta-\mathrm{F})$ isomer, we can see that $\mathrm{LP}\left(\mathrm{F}_{2}\right)$ is compensated by $F_{1}$ to balance out both lone pair orbitals so as to keep the same number of electron in each bonding. Concerning LP $\left(\mathrm{N}_{\mathrm{py}}\right)$ and LP $\left(\mathrm{N}_{2}\right)$ that are expected to bind to ruthenium atom through weak covalent bondings, both also show the same number of electron with some natural compensation. This result from NLMO theory one more confirms the bidentate state of the azopyridine ligand as demonstrated before (Affi et al. 2015). Whereas LP $(\mathrm{Ru})$, it shows that electrons from ruthenium are delocalized in the azo bonding $\mathrm{N}_{1}=\mathrm{N}_{2}$ emphasizing the metal to ligand charge transfer MLCT transition as explained in the previous article (Nobel et al. 2015). Regarding $\mathrm{LP}\left(\mathrm{N}_{1}\right)$, its occupancies are so high $(1.96 \mathrm{e})$ that it nearly delocalizes them either in $\mathrm{C}_{1}-\mathrm{N}_{\mathrm{py}}$ bonding or in $\mathrm{N}_{2}$ atom or remotely in $\mathrm{Ru}$ atom indicating that $\mathrm{N}_{1}$ is not allowed to bind to $\mathrm{Ru}$ atom.

Similarly in both isomers of $\mathrm{RuCl}_{2}$ (Azpy) 2, we can see that $\mathrm{Ru}$ $\mathrm{Cl}_{1}$ and $\mathrm{LP}\left(\mathrm{Cl}_{2}\right)$ have the same number of electrons. Also, the molecular orbital of $\mathrm{LP}\left(\mathrm{Cl}_{2}\right)$ is made of atomics orbitals of $\mathrm{Cl}_{2}$, $\mathrm{Ru}$ and $\mathrm{Cl}_{1}$ so as to get the same occupancies with $\mathrm{Ru}-\mathrm{Cl}_{1}$ bond- ing. Furthermore, LP $\left(\mathrm{N}_{\mathrm{py}}\right)$ and $\mathrm{LP}\left(\mathrm{N}_{2}\right)$ display also the same number of electrons (1.62 e) and their MOs show the bonding respectively between $\mathrm{N}_{p y}$ and $\mathrm{N}_{2}$ with $\mathrm{Ru}$. Regarding $\mathrm{LP}(\mathrm{Ru})$, it delocalizes its occupancies in the azo bond similarly to $\mathrm{RuF}_{2}(\mathrm{Az}-$ py) 2 .

When we consider $\mathrm{RuBr}_{2}$ (Azpy)2, both isomers indicate $\mathrm{Ru}-\mathrm{Br}_{1}$ and $\mathrm{LP}\left(\mathrm{Br}_{2}\right)$ as strong bonds between $\mathrm{Ru}$ and $\mathrm{Br}$ atoms since they display an equal number of electron. Moreover, $\mathrm{Ru}-\mathrm{Br}_{2}$ is compensated by $\mathrm{Br}_{1}$ to have a $\mathrm{C}_{2}$ symmetry. The same remark is made with both LP $\left(\mathrm{N}_{\mathrm{py}}\right)$ and LP $\left(\mathrm{N}_{2}\right)$ where we have almost the same distribution of occupancies. Whereas LP $\left(\mathrm{N}_{1}\right)$ and $\mathrm{LP}(\mathrm{Ru})$, they show respectively that $\mathrm{N}_{1}$ doesn't intervene in binding with ruthenium and $\mathrm{Ru}$ delocalizes in azo bond.

Regarding at last $\mathrm{RuI}_{2}$ (Azpy) ${ }_{2}$, it indicates the same observations as in $\operatorname{RuBr}_{2}$ (Azpy) 2. Anyhow, we can see that from $\mathrm{F}$ to $\mathrm{I}$, the strength of $\mathrm{Ru}-\mathrm{X}$ lowers as the contribution of the halide wanes. Therefore, the nature of $\mathrm{Ru}-\mathrm{X}$ moves slightly from ionic covalent bonding to a simple metallic bonding since the coefficient of the $\mathrm{Ru}$ metal increases.

\subsubsection{TDDFT vertical excitation energies $\Delta E(e V)$}

Table 6:Frontier Orbitals with Their Compositions (\%), Vertical Energy (Ev) of the Maximum Wavelength (Nm) with the Frequency, the Excited Lifetime $\tau(\mathrm{Ns})$ and the Main Transition Regarding Each Energy

\begin{tabular}{|c|c|c|c|c|c|c|c|}
\hline \multirow{2}{*}{ Complexes } & \multicolumn{2}{|c|}{ composition of FrontierOrbitals } & \multirow{2}{*}{$\Delta \mathrm{E}(\mathrm{eV})$} & \multirow{2}{*}{$\lambda_{\max }(\mathrm{nm})$} & \multirow{2}{*}{$f$} & \multirow{2}{*}{$\tau(\mathrm{ns})$} & \multirow{2}{*}{ Main transition } \\
\hline & HOMO & LUMO & & & & & \\
\hline \multirow{3}{*}{$\gamma-\operatorname{RuF}_{2}(\text { Azpy })_{2}$} & \multirow{3}{*}{$\mathrm{Ru}(55 \%) \mathrm{F}(17 \%)$} & \multirow{3}{*}{ Azpy (82\%) } & 1.73 & 715.14 & 0.086 & 89.14 & $\mathrm{H} \rightarrow \mathrm{L}+2(54 \%)$ \\
\hline & & & 2.27 & 547.02 & 0.099 & 45.31 & $H-2 \rightarrow L(65 \%)$ \\
\hline & & & 2.88 & 429.94 & 0.147 & 18.85 & $\mathrm{H}-3 \rightarrow \mathrm{L}(63 \%)$ \\
\hline \multirow{3}{*}{$\delta-R_{u F}(\text { Azpy })_{2}$} & \multirow{3}{*}{$\operatorname{Ru}(66 \%) F(19 \%)$} & \multirow{3}{*}{ Azpy (92\%) } & 1.48 & 838.48 & 0.084 & 125.46 & $\mathrm{H}-1 \rightarrow \mathrm{L}(70 \%)$ \\
\hline & & & 2.41 & 514.68 & 0.02 & 198.54 & $H-2 \rightarrow L+1(60 \%)$ \\
\hline & & & 2.71 & 456.66 & 0.082 & 38.12 & $\mathrm{H} \rightarrow \mathrm{L}+2(57 \%)$ \\
\hline \multirow{2}{*}{$\gamma-\mathrm{RuCl}_{2}(\mathrm{Azpy})_{2}$} & \multirow[t]{2}{*}{$\mathrm{Ru}(55 \%) \mathrm{Cl}(33 \%)$} & \multirow[t]{2}{*}{ Azpy (86\%) } & 2,15 & 577.8 & 0.066 & 75.83 & $\mathrm{H}-2 \rightarrow \mathrm{L}(65 \%)$ \\
\hline & & & 2.83 & 438.2 & 0.153 & 18.81 & $H-3 \rightarrow L(62 \%)$ \\
\hline \multirow{2}{*}{$\delta-\mathrm{RuCl}_{2}(\mathrm{Azpy})_{2}$} & \multirow{2}{*}{$\mathrm{Ru}(61 \%) \mathrm{Cl}(32 \%)$} & \multirow{2}{*}{ Azpy (93\%) } & 1.61 & 768.7 & 0.061 & 145.21 & $\mathrm{H}-1 \rightarrow \mathrm{L}(70 \%)$ \\
\hline & & & 2.32 & 533.5 & 0.012 & 355.54 & $\mathrm{H}-2 \rightarrow \mathrm{L}+1$ (68\%) \\
\hline \multirow{2}{*}{$\gamma-\operatorname{RuBr}_{2}(\text { Azpy })_{2}$} & \multirow{2}{*}{$\operatorname{Ru}(47 \%) \operatorname{Br}(42 \%)$} & \multirow{2}{*}{ Azpy (85\%) } & 1.73 & 718.01 & 0.047 & 164.42 & $\mathrm{H} \rightarrow \mathrm{L}+1(54 \%)$ \\
\hline & & & 2.12 & 584.68 & 0.038 & 134.85 & $\mathrm{H}-2 \rightarrow \mathrm{L}(51 \%)$ \\
\hline$\delta-\mathrm{RuBr}_{2}(\mathrm{Azpy})_{2}$ & $\operatorname{Ru}(53 \%) \operatorname{Br}(40 \%)$ & Azpy (92\%) & 1.5 & 823.91 & 0.042 & 242.28 & $\mathrm{H}-1 \rightarrow \mathrm{L}(70 \%)$ \\
\hline$\gamma-\mathrm{RuI}_{2}(\text { Azpy })_{2}$ & $\mathrm{Ru}(44 \%) \mathrm{I}(46 \%)$ & Azpy (85\%) & 2.12 & 585.85 & 0.01 & 514.49 & $\mathrm{H}-3 \rightarrow \mathrm{L}(58 \%)$ \\
\hline \multirow{2}{*}{$\delta-\mathrm{RuI}_{2}(\mathrm{Azpy})_{2}$} & \multirow{2}{*}{ Ru (51\%) I(44\%) } & \multirow{2}{*}{ Azpy (92\%) } & 1.47 & 841.69 & 0.023 & 461.72 & $\mathrm{H}-1 \rightarrow \mathrm{L}(70 \%)$ \\
\hline & & & 3.11 & 399.14 & 0.111 & 21.51 & $\mathrm{H} \rightarrow \mathrm{L}+2(58 \%)$ \\
\hline $\mathrm{RuCl}_{3}, 3 \mathrm{H}_{2} \mathrm{O}$ & $\mathrm{Ru}(60 \%) \mathrm{Cl}(38 \%)$ & Ru (70\%) & 2 & 516.8 & 0.061 & 65.63 & $\mathrm{H}-2 \rightarrow \mathrm{L}(98 \%)$ \\
\hline
\end{tabular}

The TDDFT calculations were performed to know of the transition states that the complexes can provide to behave as photochemical dye when they are excited. Table 6 displays the compositions of frontiers orbitals with the vertical energy required for the maximum wavelength of each transition. The main transition means here that for the same vertical energy, many transitions can be possible. Which is consistent with delocalization character of electron. Moreover, Table 7 presents the composition of molecular orbital from Homo $(\mathrm{H})$ to $\mathrm{H}-3$ and from LUMO (L) to $\mathrm{L}+3$ for each ruthenium complex. All those orbitals can actually be involved in electronic transitions. We notice that HOMO $(\mathrm{H})$ and next HOMO $(\mathrm{H}-1)$ orbitals are principally made of atomic orbital of both $\mathrm{Ru}$ and halide atoms. We can also see that the involvement of the halide atoms increases from fluorine to iodine while the contribution of $\mathrm{Ru}$ collapses. However, $\mathrm{H}-2$ is exclusively made of ruthenium atomic orbital except in Ru-I complexes where AO from iodine atom governs the molecular orbital. At last, $\mathrm{H}-3$ is dominated by orbitals of halide atoms except in complexes $\delta$-Ru-F and $\gamma$-Ru-Cl where the main contributor is azpy ligand. Regarding the group of LUMO orbitals, we can see that from L to L+3, orbital is made of Azpy ligand in almost all the complexes except for Ru-I where I is more involved as main contributor. Furthermore, both $\gamma$-Ru-I and $\delta$-Ru-I have the same diagram of orbital as confirmed in Table 5 with NLMO prediction.

Actually, the complex is considered as sensitizer if during the excitation, electron is thrown out of the metal. Hence, transitions must originate from metal orbital. Besides, the excited energy in Table 3 for each transition corresponds to energy necessary for its allowance. The lowest energy induces a more active complex. According to this analysis, we can assume that the most active complexes hitherto are $\delta$-X isomers. Moreover, all their transitions are metal to ligand charge transfer (MLCT) types. Again, we can see in $\gamma$-X complexes some transitions originated from ligand. Those transitions like $\mathrm{H}-3 \rightarrow \mathrm{L}$ are admitted to be LLCT type. Their vertical energy are high thereby reducing their sensitivity. Furthermore, we can see through iodine atoms in both isomers that orbital from ruthenium are hidden. Therefore, to have an MLCT transition, much excited energy must be required. Consequently, we can assume that I atom hampers azopyridine complexes from behaving as a photosensitizer certainly owing to its big size. In sum- 
mary, $\delta$-Ru-F isomer is assumed to be the most sensitive complex to excite semi-conductor to harvest electricity.

Moreover, the excited lifetime characterizes also a strength of complex to behave as a sensitizer (Chaofan et al. 2016). It is defined as $\tau(\mathrm{s})=$ $\frac{1.499}{f \sigma^{2}}$ where $\mathrm{f}$ is the frequency and $\boldsymbol{\sigma}$ corresponds to the wavenumber $\left(\mathrm{cm}^{-1}\right)$ necessary to allow the excitation. It also corresponds to time that a complex lasts to stay in its excited state. Hence, the high lifetime will engender the more sensitizer complex. Table 6 displays the excited lifetimes of transition states. By comparing those coming from MLTC transitions according to both Tables 6 and 7, we discover that the most sensitive complex is $\delta-\mathrm{RuF}_{2}$ (Azpy) 2 with a vertical energy of $1.48 \mathrm{eV}$ and an excited lifetime of $125.46 \mathrm{~ns}$

Table 7: Compositions (\%) of Several Molecular Orbitals Comprising Frontiers Orbitals of $\gamma_{\text {and }} \delta$-Rux 2 (Azpy) ${ }_{2}$ Complexes. Bold Data Show the Main Contributor Atom or Molecule in Performing the Molecular Orbital

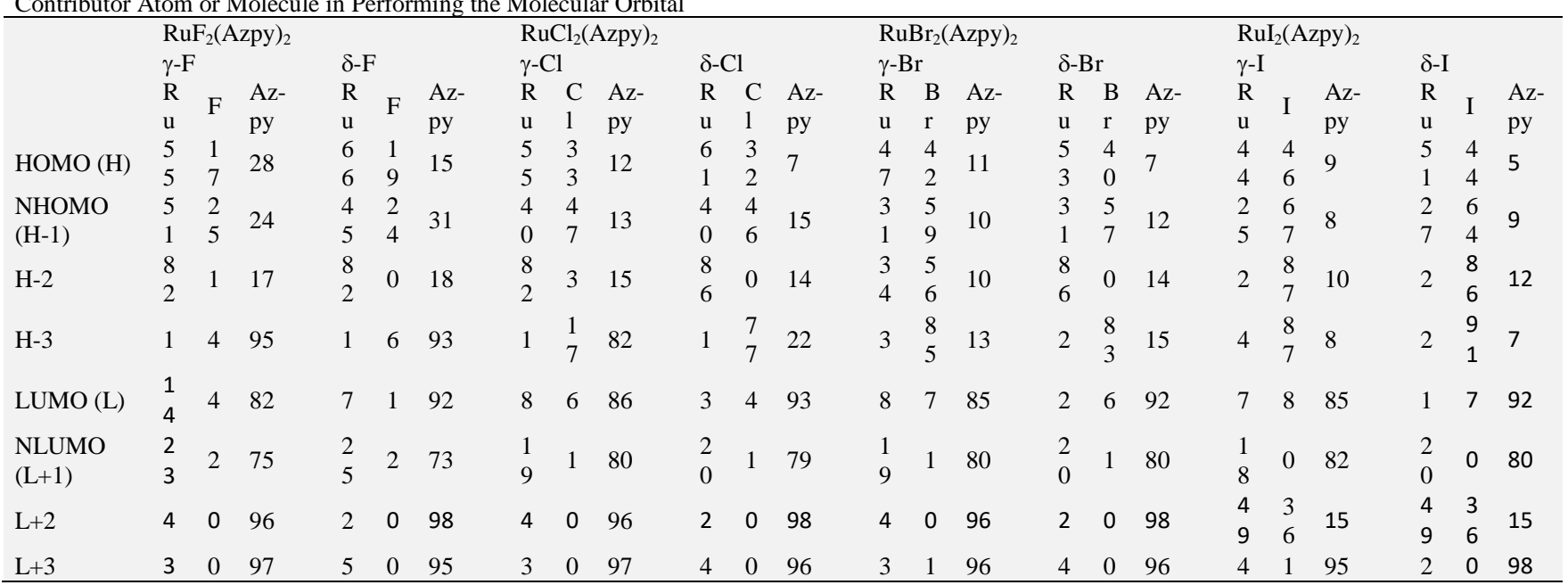

\section{Conclusion}

In this work, we were comparing efficiency of azopyridine ruthenium complexes as photosensitizers when halide atoms were replaced with DFT and TDDFT methods. First of all, the geometry was predicted and we discovered that the size of the complex depends on the halide atom's electronegativity. Then, the most eletronegative atom that is $\mathrm{F}$ reduces the size of the complex. Regarding the electronic calculation, NBO and NLMO reveal that the more negative halide atom cancels the positive charge of Ru ion in the complex and confirm the bidentate state of ligand Azpy by displaying the same number of electrons for both $\mathrm{LP}\left(\mathrm{N}_{\mathrm{py}}\right)$ and $\mathrm{LP}\left(\mathrm{N}_{2}\right)$ atoms. They show also that the strength of $\mathrm{Ru}-\mathrm{X}$ reduces when the electronegativity decreases. Whereas the TDDFT prediction, it shows up that all the complexes display an MLCT transition. But their occurrences require more excited energy when we go from $\mathrm{F}$ to $\mathrm{I}$ in the periodic table. Hence, $\mathrm{RuI}_{2}$ (Azpy) 2 cannot be used as photosensitizer as its metallic orbitals are actually hidden by the big size of the iodine atom. Whereas the $\delta$ $\mathrm{RuF}_{2}$ (Azpy)2, it is admitted to be the most sensitive molecule insofar as its metallic orbital requires the least energy to liberate electron through MLCT transition and its excited lifetime is high to maintain it in cationic shape. This result was confirmed by the frontier orbitals prediction.

Now, regarding the coming prediction, we need to replace the ruthenium atom by other atoms in same group of the periodic table. Therein, we will find out the most sensitive complex that is need to be synthesized and to be experienced.

\section{References}

[1] Adamo C \&Jacquemin D (2013) Chem. Soc. Rev, The calculations of excited-state properties with time-dependent density functional theory 42, 845-865. https://dx.doi.org/10.1039/c2cs.35394f

[2] Affi ST, Bamba K \&Ziao N (2015) Computational characterization of organometallic ligands coordinating metal: case of azopyridine ligands, JTCC $14 \quad$ (1): 1550006 https://doi.org/10.1142/S0219633615500066.

[3] Bamba K, Leger J-M, Ganier E, Bachmann C, Servat K \&Kokoh $\mathrm{KB} *(2004)$ Selective electro-oxidation of D-glucose by Rucl2 (azpy) 2 complexes as electrochemical mediators. Electro- chimicaacta 50, 3341- 3346

https://doi.org/10.1016/j.electacta.2004.12.007.

[4] Bamba K, Ouattara WP, N'Guessan KN \&Ziao N (2016) SARs Investigation of $\alpha-, \beta-, \gamma-, \delta-, \varepsilon-\mathrm{RuCl} 2(\mathrm{Azpy}) 2$ complexes as antitumor drugs. Computational Chemistry 4, 1-10. https://doi.org/10.4236/cc.2016.41001.

[5] Boa T, Krause K \& Krause R A (1988) Hydroxide-assisted stereospecific isomerization of a trans-dichlorobischelate of ruthenium (II), Inorg. Chem. 27, 759-761. https://doi.org/10.1021/ic00277a037.

[6] Chaofan S, Yuanzuo Li, Peng S \&Fengcai M (2016) An Experimental and Theoretical Investigation of the Electronic Structures and Photoelectrical Properties of Ethyl Red and Carminic Acid for DSSC Application, Materials vol. 9, p. 813 https://doi.org/10.3390/ma9100813.

[7] Chen JC, Li JL, Qian L \&Zheng KC, (2005) Electronic Structures and SARs of the Isomeric Complexes $\alpha-, \beta-, \gamma-[\mathrm{Ru}(\operatorname{mazpy}) 2 \mathrm{Cl} 2]$ with Different Antitumor Activities, Journal of Molecular Structure: THEOCHEM vol. 728, pp. 93-101. https://doi.org/10.1016/j.theochem.2005.05.005.

[8] Frisch M J, Trucks GW, Schlegel HB, Scuseria GE, Robb MA Cheeseman JR, Montgomery JA, VrevenJrT, Kudin KN, Burant JC, Millam JM, Iyengar SS, Tomasi J, Barone V, Mennucci B, Cossi M, Scalmani G, Rega N, Petersson GA, Nakatsuji H, Hada M, Ehara M, Toyota K, Fukuda R, Hasegawa J, Ishida M, Nakajima T, Honda Y, Kitao O, Nakai H, Klene M, Li X, Knox JE, Hratchian HP, Cross J B, Adamo C, Jaramillo J, Gomperts R, Stratmann RE, Yazyev O, Austin AJ, Cammi R, Pomelli C, Ochterski JW, Ayala PY, Morokuma K, Voth GA, Salvador P, Dannenberg JJ, Zakrzewski VG, Dapprich S, Daniels AD, Strain MC, Farkas O, Malick DK, Rabuck AD, Raghavachari K, Foresman JB, Ortiz JV, Cui Q, Baboul AG, Clifford S, Cioslowski J, Stefanov BB, Liu G, Liashenko A, Piskorz P, Komaromi I, Martin RL, Fox DJ, Keith T, Al-Laham MA, Peng CY, Nanayakkara A, Challacombe M, Gill PMW, Johnson B, Chen W, Wong MW, Gonzalez C \&Pople JA, Gaussian, Inc., Pittsburgh PA, 2003.

[9] Gowami S, Chakravarty AR \&Chakrovorty A (1981) Chemistry of ruthenium. 2. Synthesis, Structure, and Redox Properties of 2 (Arylazo) pyridine Complexes, Inorg. Chem., 20, 2246-2250. https://doi.org/10.1021/ic50221a061.

[10] Jorna AJ, Boelrijk AEM, Hoorn HJ \&Reedijk J (1996) Heterogenization of a Ruthenium Catalyst on Silica and Its Application in Alcohol Oxidation and StilbeneEpoxidation. Reactive \& Functional Polymers 29, 101-114. https://doi.org/10.1016/1381 5148(96)00005-3. 
[11] Krause RA \& Krause K (1980) Chemistry of bipyridyl like ligands. Isomeric complexes of ruthenium (II) with 2-(phenylazo) pyridine. Inorg. Chem. 19, 2600-2603. https://doi.org/10.1021/ic50211a024.

[12] Krause RA \& Krause K (1982) Chemistry of Bipyridyl-like ligands. 2. Mixed Complexes of ruthenium (II) with 2-phenylazopyridine: a new p-bending probe, inorg. Chem., 21, 1714-1720. https://doi.org/10.1021/ic00135a002.

[13] Misra TK, Das D \&Sinha C (1997) Chemistry of azoimidazoles: synthesis, spectral characterization and redox properties of bis $(\mathrm{N}$ (1)-alkyl-2-(arylazo)imidazole) copper (I) and silver(I) complexes. Polyhedron 16, 23, 4163-4170. https://doi.org/10.1016/S02775387(97)00127-7.

[14] Nobel NK, Bamba K, Patrice OW \&Ziao N (2017) NBO population analysis and electronic calculation of four azopyridine ruthenium complexes by DFT method. Computational Chemistry, 5, 51-64. http://dx.doi.org/10.4236/cc2017.51005

[15] Reed AE, Curtiss LA \&Weinhold F, (1988) Intermolecular interactions from a natural bond orbital, donor-acceptor viewpoint, Chem. Rev. 88, 899-926. https://doi.org/10.1021/cr00088a005.

[16] Reedijk J \&Bouwman E (1999), bioinorganic catalysis (Dekker, New-york). https://doi.org/10.1201/9780203908457.

[17] Reedijk J (2003) new clues for platinum antitumor chemistry: kinetically controlled metal binding to DNA, PNAS 100(7), and 3611-3616. https://doi.org/10.1073/pnas.0737293100.

[18] Shriver DF \& Atkins PW (1999) inorganic chemistry, 3rd edition, Oxford University Press, 406.

[19] Velders AH, Van der Schilden K, Hoste ACG, Reedijk J, Kooijman H \& Speck A L (2004) Dichlorobis(2phenylazopyridine)ruthenium(II) complexes: characterization, spectroscopic and structure properies of four isomers. Dalton Trans. 448-455. https://doi.org/10.1039/B313182C.

[20] Weinhold F \& Landis CR (2001) Chem. Educ. Res. Pract. Eur., Natural Bond Orbitals and extensions of Localized bonding concepts, chemistry education Research and Practice 2, 91-104. 